Katarzyna Olbrycht*

Cieszyn

\title{
Współczesne obszary pedagogiki chrześcijańskiej
}

Dorobek historyczny i rozwój pedagogiki chrześcijańskiej jest w środowiskach identyfikujących się $\mathrm{z}$ tą dziedziną pedagogiki przedmiotem wielu prac między innymi autorów związanych z Zespołem Pedagogiki Chrześcijańskiej funkcjonującym przy Komitecie Nauk Pedagogicznych PAN, z czasopismem „Paedagogia Christiana”, z akademickimi wydziałami teologicznymi i ośrodkami prowadzącymi związane z tym zakresem kierunki studiów i specjalności. Jest też tematem licznych publikacji (żeby wspomnieć tylko wydany w 2010 roku w Toruniu tom Pedagogika chrześcijańska. Tradycja, wspótczesność, nowe wyzwania pod redakcją J. Michalskiego i A. Zakrzewskiej). Pokazują one, że zakres pedagogiki chrześcijańskiej rozumiany i określany jest różnie. W przedstawianym tekście proponuję spojrzenie na zakres tej dziedziny przez pryzmat jej tożsamości. Chciałabym rozważyć dwa wymiary tejże tożsamości: przedmiot badań oraz przyjmowaną w niej perspektywę antropologiczną i aksjologiczną.

\section{Tożsamość pedagogiki chrześcijańskiej - w świetle tożsamości pedagogiki}

Określenie tożsamości pedagogiki chrześcijańskiej wymaga wyjścia od tożsamości pedagogiki jako nauki. Ta problematyka doczekała się już wielu opracowań (autorstwa między innymi S. Wołoszyna, T. Hejnickiej-Bezwińskiej, B. Śliwerskiego, S. Palki). Wnikliwą analizę specyfiki „,pedagogiczno-

* Prof. zw. dr hab. Katarzyna Olbrycht jest kierownikiem Zakładu Edukacji Kulturalnej w Wydziale Etnologii i Nauk o Edukacji Uniwersytetu Śląskiego w Cieszynie. 
ści" nauk o wychowaniu, w tym - pedagogiki, podjął w swojej najnowszej pracy Marian Nowak. Według tego autora istotą „pedagogiczności”, a więc tożsamości pedagogicznej nauk o wychowaniu, jest ich przedmiot - wychowanie człowieka widzianego w całej jego integralności, wychowanie ujmowane wraz z jego wielorakimi uwarunkowaniami ${ }^{1}$. Cele pedagogiki jako nauki powinny uwzględniać, obok teoretycznego, przede wszystkim jej praktyczny charakter. Oznacza to przyjęcie, że pedagogika powinna być nie tylko nauką „o wychowaniu”, ale nauką uprawianą „dla wychowania”. Wymaga to systemowego podejścia do działalności wychowawczej, a więc brania pod uwagę całej rzeczywistości wychowawczej, w jakiej działalność ta, wraz z formacja jako przygotowaniem do samowychowania, przebiega.

Można przyjąć, że dotyczy to również pedagogiki chrześcijańskiej².

Chciałabym nieco doprecyzować, ale i poszerzyć to ujęcie, proponując by za przedmiot nauk pedagogicznych uznać dzialanie pedagogiczne ${ }^{3}$. Działanie to, obejmujące wąsko rozumiane wychowanie, samowychowanie, kształcenie i samokształcenie, ma charakter złożony i ze względu na swoją specyfikę wyznacza przestrzeń o dwu wymiarach: celowo-racjonalnym i interakcyjno-dialogowym. Jest to działanie zorientowane na zasadniczy cel - wspieranie rozwoju wychowanka/ucznia. Tworzą go z jednej strony formalne i nieformalne działania, podejmujące szczegółowe cele-zadania i operujące racjonalnie dobieranymi środkami, z drugiej - działania pedagogów jako działania stanowiące nie tyle realizację zadań, co wcielanie w życie własnej postawy pedagogicznej. Postawa ta obejmuje postawę wobec wychowanka/ucznia oraz postawy wobec własnej roli jako pedagoga (wychowawcy/nauczyciela). Postawa pedagoga jest w tym ujęciu nie tylko czynnikiem warunkującym przebieg działania celowo-racjonalnego. Jest odrębnym wymiarem działania, które może być podejmowane także poza działaniem celowo-racjonalnym, poza realizacją szczegółowych, określonych programowo zadań, jako interakcja, w centrum której jest gotowość do

${ }^{1}$ Por. M. Nowak, Pedagogiczny profil nauk o wychowaniu. Studium z odniesieniami do pedagogiki pielegniarstwa, Lublin 2012.

${ }^{2}$ M. Nowak, od początku istnienia Zespołu Pedagogiki Chrześcijańskiej jego przewodniczący, przedstawia w jednym ze swoich teksów historię chrześcijańskiej myśli pedagogicznej i stara się ukazać jej specyfikę, zwracając uwagę, iż ze względu na swą wieloaspektowość jest ona $\mathrm{w}$ znacznym zakresie nauką teologiczną a równocześnie nauką społeczną i humanistyczna, wreszcie praktyczną nauka o wychowaniu. Por. M. Nowak, Specyfika, wyzwania, możliwości i perspektywy pedagogiki chrześcijańskiej w Polsce, w: J. Michalski, A. Zakrzewska (red.), Pedagogika chrześcijańska. Tradycja, współczesność, nowe wyzwania, Torun 2010, s. 13-35.

${ }^{3}$ Szerokie uzasadnienie teoretyczne takiego ujęcia oraz jego wyjaśnienie przedstawiłam w pracy Sztuka a działania pedagogów, Katowice 1987. 
dialogu i jego podejmowanie. Działanie pedagogiczne jest więc działaniem zorientowanym na określone zadania i równocześnie działaniem wyrażającym określoną postawę (w sferze poznawczej, emocjonalnej i motywacyjno-działaniowej). Te wymiary mogą być harmonijnie łączone i równoważone, może też dochodzić do dominacji któregoś z nich, co może być wynikiem określonej sytuacji, ale może też stanowić wyraz świadomej decyzji bądź cech osobowościowych pedagoga. Ktoś może na przykład poprawnie i skutecznie pracować w danej instytucji oświatowej, realizując wyznaczone cele i uzyskując zakładane efekty, a równocześnie świadomie dystansować się od roli pedagoga zarówno w sensie postawy przejawianej wobec wychowanka w sytuacji pozainstytucjonalnej, nieformalnej, jak i w sensie postawy wobec własnej roli - podkreślając granicę i różnice między własnym życiem prywatnym a działaniami realizowanymi zawodowo. Taką relację zakłada coraz częstsza dziś interpretacja działań pedagogicznych jako świadczenia możliwie precyzyjnie określonych usług edukacyjnych w relacji usługodawca-usługobiorca, weryfikowanych możliwie precyzyjnym pomiarem.

Wymiary te nie są związane jedynie z przyjmowaniem bądź nie konkretnych celów, z podejściem bardziej prakseologicznym, czy raczej interakcyjno-dialogowym. Są równocześnie wymiarem aksjologicznym działania pedagogicznego. Przede wszystkim zakładają stosunek do wychowania jako takiego i do jego celów jako wartości. W szczegółowej treści i formach zależą z jednej strony od celów i zadań widzianych przez pedagoga, rodzica, a zależnie od wieku - także wychowanka, przez pryzmat wartości, z jakich wynikają i jakim służą. Z drugiej - od postaw uczestników działań pedagogicznych, głównie pedagogów, ale z wiekiem wychowanków, w coraz większym stopniu również od ich postawy wobec własnego rozwoju i roli w nim pedagoga, ostatecznie - wobec determinacji w pracy nad własnym rozwojem. Postawa wobec działań pedagogicznych jest wyrazem stosunku uczestników tych działań do wartości człowieka i człowieczeństwa, człowieka w roli wychowanka/ucznia i wychowawcy/nauczyciela, w przypadku pedagoga - stosunku do siebie jako pedagoga - z konsekwencjami dla kształtu własnej relacji z wychowankiem. Stosunek ten wynika $\mathrm{z}$ wartości, jaką przypisuje się własnej roli w tej relacji i szerzej - w procesie wychowania, w przypadku wychowanka - jest to stosunek do siebie jako wychowanka i własnych relacji z innymi uczestnikami działań wychowawczych.

Tak rozumiana „pedagogiczność” dotyczy również pedagogiki chrześcijańskiej w sensie jej przedmiotu badań i przyjmowanej w badaniach perspektywy antropologiczno-aksjologicznej.

Tożsamość pedagogiki opartą na przedmiocie badań dobrze wyjaśnia ujęcie Stefana Kunowskiego, jednego z głównych polskich teoretyków pe- 
dagogiki, szczególnie pedagogiki katolickiej. Kunowski wyróżnia rodzaje wiedzy wytwarzanej w ramach pedagogiki, uwzględniając całą jej różnorodność i złożoność, jako nauki o wychowaniu człowieka i jego rozwoju. Koncepcja ta wyodrębnia cztery zasadnicze działy pedagogiki: pedagogikę praktyczną (lub empiryczną), wykorzystującą praktyczne doświadczenia wychowawcze konkretnych wychowawców i środowisk, pedagogikę opisową (lub eksperymentalną) uogólniającą doświadczenia praktyczne i sprawdzającą eksperymentalnie nowe rozwiązania wychowawcze, pedagogikę normatywna, ustalająca - na drodze analiz koncepcji człowieka, wartości i kultury - wartości, ideały, cele i normy wychowania, wreszcie - pedagogikę teoretyczną (ogólną), która w oparciu o pozostałe działy bada i ustala ogólne prawidłowości wychowawczego działania i wywołanego nim rozwoju człowieka. Taki sposób widzenia pedagogiki pociaga za sobą uznanie zasadności jej sytuowania w różnych grupach i obszarach nauk - praktycznych i teoretycznych, humanistycznych i społecznych ${ }^{4}$.

Pedagogika chrześcijańska może być i w praktyce jest uprawiana we wszystkich wyodrębnionych przez Kunowskiego zakresach. Jako pedagogika empiryczna (praktyczna) zajmuje się badaniem praktycznych form realizowania wychowania chrześcijańskiego w różnych nieformalnych i formalnych środowiskach, przez różne osoby podejmujące niezinstytucjonalizowane i zinstytucjonalizowane działania wychowawcze. Jako pedagogika opisowo-eksperymentalna bada systemy wychowawcze (na przykład pedagogie związane $\mathrm{z}$ charyzmatem wychowawczym poszczególnych Zgromadzeń Zakonnych ${ }^{5}$, ruchów religijnych obejmujących swoim programem pracę wychowawczą czy konkretnych postaci różnych czasów, na podstawie działań i poglądów których można zrekonstruować ich program wychowawczy), sprawdza różne rozwiązania metodyczne i organizacyjne.

Jednak specyfikę pedagogiki chrześcijańskiej szczególnie wyraźnie określa to, iż z natury rzeczy (deklarowanej nazwy) jest pedagogiką normatywną. U podstaw jej wyodrębniania leży chrześcijańska koncepcja człowieka, wartości i kultury. Jej treść jako pedagogiki normatywnej określa ideał wychowania chrześcijańskiego, cele i zasady działań zorientowanych na realizację tego ideału. Źródłem celów jest doktryna chrześcijańska i dokumenty Kościoła oraz oparta na religii chrześcijańskiej antropologia i aksjologia. Przyjmowana hierarchia i struktura celów szczegółowych prowadzi

${ }^{4}$ Por. S. Kunowski, Podstawy wspótczesnej pedagogiki, Warszawa 1993, s. 38.

${ }_{5}^{5}$ Przykładem badań z tego obszaru może być opublikowana ostatnio praca: J. Kostkiewicz (red.), Pedagogie Katolickich Zgromadzeń Zakonnych. Historia i współczesność, t. I, Kraków 2012. 
do wypracowywania $\mathrm{w}$ ramach pedagogiki chrześcijańskiej między innymi pedagogik poszczególnych wyznań chrześcijańskich (jak dotąd głównie pedagogiki katolickiej). Wreszcie uprawianie pedagogiki chrześcijańskiej w wymiarze ogólnym byłoby uogólnianiem prawidłowości związanych z ustalaniem i realizacją przyjętych celów wychowania chrześcijańskiego, $\mathrm{z}$ wykorzystywanymi $\mathrm{w}$ jego ramach formami i metodami, uzyskiwanymi doświadczeniami.

Pedagogika chrześcijańska, wskazując w sferze normatywnej szczegółowe zadania wychowania chrześcijańskiego, powinna w sferze empirycznej, opisowej i eksperymentalnej podejmować (i podejmuje) badania nad ich konkretną realizacją we wszystkich środowiskach wychowawczych, grupach wiekowych, uwarunkowaniach społecznych i kulturowych.

Szczegółowa treść pedagogiki chrześcijańskiej we wszystkich wyodrębnionych według koncepcji S. Kunowskiego jej działach, określana ze względu na źródła i rodzaje wytwarzanej wiedzy oraz przedmiot jej badań, wynikałaby z przyjętego rozumienia wychowania chrześcijańskiego. W świetle ujęcia M. Nowaka obejmowałaby więc całą rzeczywistość wychowawczą związaną z budowaniem w ludziach człowieczeństwa w znaczeniu przyjętym w religii chrześcijańskiej i opartym na niej chrześcijańskim myśleniu. Idąc za takim sposobem myślenia o wychowaniu chrześcijańskim, pedagogika chrześcijańska, w sferze normatywnej deklarująca jako swą podstawę religię chrześcijańską, powinna swój przedmiot zakreślić szeroko.

Równocześnie, zgodnie z przyjętym rozumieniem „działania pedagogicznego", przedmiot pedagogiki chrześcijańskiej obejmowałby działania w zakresie realizacji szczegółowych celów wychowania chrześcijańskiego oraz celów działań pedagogicznych widzianych w perspektywie chrześcijańskiej, a także postaw uczestników działań pedagogicznych wobec siebie i innych, postaw zgodnych z antropologią i aksjologią chrześcijańską. Działanie podejmujące realizację celów wychowania chrześcijańskiego dotyczyłoby wprowadzania $\mathrm{w}$ religię chrześcijańska, to znaczy kształcenia $\mathrm{w}$ zakresie wiedzy o tej religii i życiu chrześcijańskim, przygotowującego do życia chrześcijańskiego. Działanie dotyczące realizacji celów wychowawczych formułowanych $\mathbf{z}$ perspektywy chrześcijańskiej dotyczyłoby nie tyle odnoszenia celów do religii chrześcijańskiej, ile uwzględniania w nich założeń antropologicznych i aksjologicznych przyjmowanych w chrześcijaństwie. Wychowanie chrześcijańskie obejmowałoby więc wychowanie religijne, ale i wychowanie oparte na antropologicznych i aksjologicznych założeniach religii chrześcijańskiej. 


\section{Wychowanie chrześcijańskie - jako wychowanie religijne}

Religia, obok nauki, moralności, języka i sztuki stanowi najważniejszą sferę kultury. Jak pisze Andrzej Bronk „w każdej ze swych rozlicznych manifestacji religia (religie) jest złożonym tworem kulturowym, składającym się z części doktrynalnej, kultowej, obrzędowej, liturgicznej i instytucjonalnej, wielorako się przeplatających"6. Współcześnie podkreśla się wolność religijna jako prawo osoby ludzkiej ${ }^{7}$. O roli związków edukacji i religii pisze w licznych swych publikacjach J. Michalski ${ }^{8}$. M. Nowak w przytaczanej pracy, powołując się na licznych autorów, uzasadnia tezę, według której wymiar religijny jest podstawowym wymiarem człowieczeństwa, jest bowiem głównym czynnikiem motywującym człowieka do wysiłku budowania siebie9.

Niezbędnym elementem wychowania człowieka jest więc wychowanie religijne. Celem wychowania religijnego jest kształcenie: (a) poglądu na świat odwołującego się, obok wiedzy filozoficznej i wiedzy nauk szczegółowych, do wiedzy teologicznej dającej racjonalne ramy dla wiary ${ }^{10}$, (b) orientacji życiowej jako systemu wartości-celów opartych na religijnej interpretacji sensu życia, oraz (c) postaw wobec siebie, świata, innych, które umożliwiałyby realizację przyjętej orientacji życiowej zakorzenionej w wybranej religii.

Przyjmuję, iż wychowanie religijne obejmuje trzy obszary: edukację religijna, wychowanie do religijności oraz wychowanie do- i w określonej religii. Jest to ujęcie nieco różniące się od tego, które religijność uznaje za akt łączący przedmiot religijności, jej podmiot (człowieka religijnego) i relację podmiotu religijnego do religijnego przedmiotu ${ }^{11}$. W konsekwencji wychowanie do religijności włączałoby wychowanie do określonej religii. Dla jaśniejszego określenia odrębności tych zakresów w działaniach wychowawczych proponuję ich rozdzielenie.

${ }^{6}$ A. Bronk, Pluralizm religijny i prawdziwość religii, w: H. Zimoń (red.), Religia w świecie współczesnym. Studia religiologiczne, Lublin 2000, s. 616.

${ }^{7}$ Por. Deklarację Praw Człowieka ONZ ale i deklaracje Soboru Watykańskiego II O wolności religijnej oraz O stosunku Kościoła do religii niechrześcijańskich, w: Sobór Watykański II, Konstytucje, dekrety, deklaracje, Poznań 1967.

${ }^{8}$ Por. m.in. J. Michalski, Edukacja i religia jako źródła rozwoju egzystencjalno-kognitywnego. Studium hermeneutyczno-krytyczne, Torun 2004.

${ }_{9}$ Por. M. Nowak, Pedagogiczny profil, s. 323-324.

${ }^{10}$ Rozróżnienie światopoglądu powstającego na drodze irracjonalnej i racjonalnej, o której jest tu mowa, wprowadza Stanisław Kamiński w rozdziale Typy ludzkiej wiedzy, w książce Jak filozofować?, Lublin 1989.

${ }_{11}$ Takie rozumienie religijności przytacza J. Michalski w cytowanej książce Edukacja i religia, s. 116-117. 
Objaśnijmy krótko przyjęte tu zakresy.

I. Edukacja religijna dotyczy: (1) wiedzy o religii jako zjawisku kulturowym, o jej istocie, roli w życiu jednostek i społeczeństw; (2) wiedzy o własnej religii (wyznawanej); (3) o religii własnej wspólnoty kulturowej i społecznej (jeśli jest inna od wyznawanej); (4) wiedzy o innych religiach, szczególnie religiach występujących lokalnie.

II. Wychowanie do religijności jest kształceniem otwartości i wrażliwości na transcendencję, potrzeby szukania sensu życia i śmierci, kształceniem postawy powagi wobec siebie, świata i innych. Przez postawę tę rozumiem pogłębianie refleksyjności i samowiedzy, dążenie do prawdy oraz podejmowanie odpowiedzialności za siebie, innych i świat, wynikającej z przyjętej prawdy religijnej. Wychowanie do religijności w sferze praktycznej kształci szacunek wobec symboli, organizacji, form i miejsc kultu religijnego. Szacunek wyrastający ze świadomości, iż stosunek do sacrum jest szczególnie wrażliwym, głębokim doświadczeniem człowieka, związanym z poczuciem jego godności i tożsamości, wymagającym respektu niezależnie od osobistego stosunku do religii (potrzebę kształcenia w sobie religijności rozważa odwołując się do różnych religii między innymi Jarosław Rudniański w książce Przestrzeń wiary ${ }^{12}$ ).

III. Wychowanie do określonej religii (formacja w określonej religii, jak określa to między innymi Hansemann ${ }^{13}$ ) jest wprowadzaniem w doktrynę, praktyki religijne danej religii oraz kształceniem postaw opartych na wierze związanej z daną religią (według przytoczonego wyżej rozumienia religii A. Bronka).

W przypadku religii chrześcijańskiej, a co za tym idzie - pedagogiki chrześcijańskiej, każde z tych zadań przyjmuje specyficzną treść, wynikającą z treści chrześcijaństwa. „Edukacja religijna” nie jest jedynie elementem edukacji kulturowej uzasadnionej ogólną potrzebą kompetencji kulturoznawczych. Zdobywanie i pogłębianie wiedzy o istocie religii i o religiach jest wyrazem szacunku do drugiego człowieka w jego religii, szacunku do innych kultur - w tym do ich religii i religijności ich członków, gotowości do dialogu z zachowaniem wolności religijnej każdej ze stron. „Wychowanie do religijności" jest wychowaniem do wrażliwego odczytywania, rozumienia i szanowania religijności każdego człowieka, ale równocześnie wychowaniem kształcącym potrzebę poszukiwania prawdy, dobra i piękna, otwierania się na transcendencję, kontemplowania świata, poszukiwania jego sensu, do podziwu i zachwytu nad światem, prowadzących do odkrywania w nim objawiającego się Boga. Kształcenie religijności wiąże się z budowaniem

12 J. Rudniański, Przestrzeń wiary w cywilizacji współczesnej, Poznań 1998.

${ }^{13}$ G. Hansemann, Wychowanie religijne, Warszawa 1988. 
osobowego człowieczeństwa. Religijność i dojrzałość osobowa wzajemnie się wzmacniają i warunkuja.

Wreszcie „wychowanie do- i w religii chrześcijańskiej” jest wychowaniem do wiary i w wierze chrześcijańskiej, opartej na miłości Chrystusa, stale pogłębianej i wprowadzanej w życie.

We wszystkich tych zakresach działanie pedagogiczne obejmuje działania celowo-racjonalne i interakcyjno-dialogowe, realizację określonych zadan i realizację postaw. W wychowaniu chrześcijańskim postawy przyjmują dodatkowy charakter ze względu na fakt łączenia postaw osobowych i chrześcijańskich. Te ostatnie wymienił i omówił, relacjonując prace Soboru Watykańskiego II, Karol Wojtyła w książce: U podstaw odnowy ${ }^{14}$. Są to według Wojtyły (co wielokrotnie potwierdzał jako Papież) postawa powierzenia siebie Bogu, postawa misyjna, postawa świadectwa, postawa uczestnictwa w troistym posłannictwie Chrystusa - kapłańskim, prorockim i królewskim, postawa ludzkiej tożsamości i solidarności, postawa odpowiedzialności chrześcijańskiej, postawa ekumeniczna, postawa apostolska, wreszcie - postawa budowania Kościoła jako wspólnoty.

\section{Wychowanie chrześcijańskie - związek wymiaru osobowego i religijnego}

Wychowanie chrześcijańskie jest przede wszystkim wychowaniem do osobowego kontaktu z Chrystusem. Ideałem wychowania wyznaczającym jego zakres i treść jest nowy humanizm (oparty, według Jana Pawła II, w sferze antropologii filozoficznej - na koncepcji człowieka jako osoby, oraz w sferze antropologii teologicznej, ukazującej teologiczne uzasadnienie osobowej godności człowieka, na uznaniu iż człowiek jest obrazem Boga i dzieckiem Bożym).

Wychowanie człowieka jako osoby - istoty obdarzonej bezwarunkową godnością, wolnej i rozumnej, integralnej w swej fizyczności, psychiczności i duchowości, zorientowanej na wartości wyższe - na poznawanie prawdy, dążenie do dobra, kontemplowania i tworzenia piękna, istoty spełniającej się w bezinteresownej miłości i w byciu dla innych, w dążeniu do dobra wspólnego we wspólnocie, zakłada wychowanie do wartości osobowych (wartości fundamentalnych i szczegółowych - służących rozwojowi i ochronie osoby). W Deklaracji o Wychowaniu Chrześcijańskim Soboru Watykańskiego II czytamy:

${ }^{14}$ K. Wojtyła, U Podstaw odnowy. Studium o realizacji Vaticanum II, Kraków 2003. 
Wszyscy ludzie jakiejkolwiek rasy, stanu i wieku mają jako cieszące się godnością osoby nienaruszalne prawo do wychowania odpowiadającego ich własnemu celowi, dostosowanego do właściwości wrodzonych, różnicy płci, kultury i ojczystych tradycji, a równocześnie nastawionego na braterskie z innymi narodami współżycie dla wspierania prawdziwej jedności i pokoju na ziemi. Prawdziwe zaś wychowanie zdąża do kształtowania osoby ludzkiej w kierunku jej celu ostatecznego, a równocześnie do dobra społeczności, których człowiek jest członkiem i w których obowiązkach, gdy dorośnie, będzie brał udział $(\mathrm{DWCH} 1)^{15}$.

Wychowanie chrześcijańskie obejmuje więc wychowanie człowieka jako osoby, oznaczające wychowanie do osobowego rozwoju i spełniania się, oraz wychowanie człowieka jako chrześcijanina, świadomego swojej wiary, przejawiającego postawę tożsamości i odpowiedzialności chrześcijańskiej, stale pogłębiającego swoje życie chrześcijańskie, dążącego do świętości - co podkreślał Jan Paweł II mówiąc o ,pedagogice świętości”. Wychowanie to powinno kształcić postawę gotowości świadczenia o wierze, przekazywania wiary, nie indoktrynacji, ale dzielenia się wiarą. Udział w ewangelizacyjnej misji Kościoła jest dla chrześcijan wyzwaniem, które nabiera nowej aktualności na początku XXI wieku, tym samym stając się nowym wyzwaniem dla wychowania chrześcijańskiego. Zakłada przygotowanie chrześcijan do otwartego, czytelnego, wiarygodnego funkcjonowania w sytuacji rosnącej sekularyzacji, zagubienia religijnego wielu ludzi, chaosu aksjologicznego, przy równoczesnym nasilaniu się potrzeb związanych z duchowością ${ }^{16}$. Ten właśnie wymiar wyrastający z antropologii teologicznej stanowi o istocie wychowania chrześcijańskiego, co podkreśla Deklaracja o wychowaniu chrześcijańskim Soboru watykańskiego II. Czytamy w niej: „Wszyscy chrześcijanie [...] mają prawo do wychowania chrześcijańskiego. Wychowanie to zdąża nie tylko do pełnego rozwoju osoby ludzkiej [...], lecz ma na względzie przede wszystkim to, aby ochrzczeni, wprowadzani stopniowo w tajemnice zbawienia, stawali się z każdym dniem coraz bardziej świadomi otrzymanego daru wiary" (DWCH 2). Dokument ten wśród celów wychowania chrześcijańskiego wyróżnia: przygotowanie do chwalenia Boga „w duchu i prawdzie” - szczególnie w kulcie liturgicznym, do dążenia do doskonałości poprzez życie ,wedle nowego człowieka w sprawiedliwo-

${ }^{15}$ Deklaracja o wychowaniu chrześcijańskim Soboru Watykańskiego II, w: Sobór Watykański II - w tekście DWCH z odnośnym numerem.

${ }^{16}$ Wyzwanie to podkreśla w swoich wystąpieniach Benedykt XVI. Było ono też tematem ostatniego Synodu Biskupów zwołanego w związku z Jubileuszem 50-lecia otwarcia Soboru Watykańskiego II poświęconego „nowej ewangelizacji”. 
ści i świętości prawdy", do przyczyniania się do rozwoju Kościoła jako Ciała Mistycznego Chrystusa, do świadczenia i uzasadniania własnej nadziei i włączania się w chrześcijańskie kształtowanie świata.

Wychowanie chrześcijańskie jako wychowanie religijne jest zadaniem dla katechezy domowej, szkolnej, prowadzonej w kościele, ale i w mediach. Jednocześnie jest poważnym wyzwaniem dla podjętego obecnie przez Kościół Powszechny programu nowej ewangelizacji, wychodzącej do ludzi w różnym stopniu wierzących, poszukujących, ale także dystansujących się do wiary.

Rdzeniem wychowania do- i w religii chrześcijańskiej jest wychowanie do- i w wierze chrześcijańskiej. Jednak podstawą rozwoju świadomości i tożsamości chrześcijańskiej oraz kształtowania się postaw chrześcijańskich jest dojrzałość osobowa. Szeroko rozumiane wychowanie chrześcijańskie musi więc uwzględniać oba te wymiary - religijny i osobowy - ukazując ich integralny związek. Tym samym pedagogika chrześcijańska powinna i najczęściej traktuje obie te sfery wychowania jako przedmiot swoich badań, ale i jako dziedziny, do których adresuje się praktyczne wnioski i oparte na nich wskazania. Jej kluczowy zakres - normatywny - musi uwzględniać oba ujęcia antropologiczne (osobowe i religijne), formułować cele i zasady odnoszące się do obu sfer, opierać się na aksjologii osobowej i chrześcijańskiej. W. Chudy, etyk, wybitny znawca personalizmu chrześcijańskiego i nauczania Jana Pawła II, wyjaśniał, że wartości chrześcijańskie nie różnią się w swej istocie od wartości ogólnoludzkich, wartości broniących człowieka i jego godności. Różnica wynika z faktu, że wartości chrześcijańskie są nierozłącznie związane ze swoim źródłem i uzasadnieniem - Chrystusem jako szczytem i wzorem człowieczeństwa ${ }^{17}$.

\section{Wychowanie chrześcijańskie - sens bezpośredni i pośredni}

Wychowanie do- i w wierze chrześcijańskiej jako wychowanie religijne jest wychowaniem chrześcijańskim w sensie bezpośrednim.

Można jednak mówić o wychowaniu chrześcijańskim także w sensie pośrednim, jako wychowaniu opartym na religii. Oparcie się w wychowaniu na religii chrześcijańskiej oznacza przede wszystkim wychowanie osobowe realizowane w postawie chrześcijańskiej. Wyjaśnijmy to rozróżnienie. Przez wychowanie chrześcijańskie realizowane bezpośrednio będzie tu rozumiane wychowanie programowo odwołujące się do religii chrześcijańskiej, zaś przez wychowanie chrześcijańskie realizowane pośrednio - wychowanie

17 Por. W. Chudy, Pedagogia godności. Elementy etyki pedagogicznej, Lublin 2009. 
osobowe, realizowane przez wychowawców postępujących i działających zgodnie z chrześcijańską wizją człowieka, wychowawców nieukrywających religijnego wymiaru własnej orientacji światopoglądowej, jednak niewprowadzających celów i treści religijnych w program realizowanych działań.

Bezpośredni sens wychowania chrześcijańskiego, stanowiący główny jego zakres, sprowadzałby się do wychowania religijnego $\mathrm{w}$ znaczeniu realizacji jednoznacznie określonych, sformułowanych i zadeklarowanych celów zawartych w przyjętym programie wychowania chrześcijańskiego. Realizacja pośrednia - oznaczałaby działania zgodne z koncepcją człowieka jako osoby, podejmowane przez pedagogów utożsamiających się z chrześcijaństwem, kierujących się w swoich działaniach wychowawczych, niezależnie od ich szczegółowego programu, postawa chrześcijańską. Wychowanie chrześcijańskie w sferze działań pośrednich - czyli jako wychowanie oparte na religii chrześcijańskiej - byłoby więc przyjmowaniem przez wychowawców (w działaniu wychowawczym i w pozostałych sferach życia, ze względu na bycie dla wychowanków przykładem) postawy chrześcijańskiej, wyrażające się realizowaniem wychowania osobowego i własną osobową wiarygodnością opartą na chrześcijańskiej wizji człowieka.

\section{5. „Perspektywa chrześcijańska” w uprawianiu pedagogiki chrześcijańskiej}

Analizując tożsamość pedagogiki chrześcijańskiej warto by na koniec wspomnieć o zagadnieniu jej uprawiania „w perspektywie chrześcijańskiej”. Nie chodzi tu oczywiście o ideologizację czy doktrynerstwo, które wpływałoby na obiektywizm naukowy prowadzonych w jej ramach badań. Przyjęcie tej perspektywy oznacza: z jednej strony - integralne widzenie człowieka a więc przeciwstawianie się wszelkim redukcjonizmom $\mathrm{w}$ jego badaniach, z drugiej - wyostrza widzenie procesu wychowawczego i jego uwarunkowań w świetle antropologii chrześcijańskiej i chrześcijańskich postaw, tym samym dostrzeganie problemów szczególnie ważnych i pilnych. Inspiruje i motywuje do ich podejmowania. Ważność i aktualność problemów dotyczy obu wyróżnionych zakresów.

W zakresie wychowania chrześcijańskiego w sensie pośrednim - jako wychowania osobowego opartego na religii chrześcijańskiej - wiąże się między innymi z badaniem wpływu warunków zewnętrznych na rozwój osobowy i osobowe funkcjonowanie uczestników procesów wychowawczych, ale i na dominujący w życiu społecznym stosunek do człowieka jako osoby. $\mathrm{W}$ polu zainteresowań pedagogiki chrześcijańskiej powinny się więc znaleźć także struktury społeczne, praktyki kulturowe, wzory myślenia i działania 
funkcjonujące $\mathrm{w}$ obiegu społecznym, w tym poprzez media i w mediach, analizowane ze względu na przestrzeń, jaką tworzą dla wychowania chrześcijańskiego zarówno jako wychowania religijnego, jak i opartego na religii.

W zakresie wychowania chrześcijańskiego w sensie bezpośrednim jako wychowania religijnego - pedagogika chrześcijańska powinna podejmować problemy, pozwalające wskazywać, obok pozytywnych doświadczeń i efektów, także źródła i mechanizmy błędów, które mogą negatywnie wpływać na kształtowanie świadomości chrześcijańskiej i chrześcijańskich postaw. Wydaje się, że wśród tych słabszych punktów, które wymagałyby sprawdzenia na drodze rzetelnych badań i poszukiwania możliwości ich korygowania, można by hipotetycznie wskazać ${ }^{18}$ :

- przywiązywanie w działaniach pedagogicznych zbyt małej wagi do roli religii i religijności w życiu człowieka, w tym - brak wyraźnej reakcji na tendencje sprowadzania ich do sfery folkloru bądź całkowicie prywatnej sfery życia człowieka, pozostającej na marginesie znaczących decyzji i zachowań;

- marginalizowanie znaczenia świadomości i znajomości religijnego wymiaru kultury (w różnych skalach: kultury rodzinnej, lokalnej, regionalnej, narodowej, ponadnarodowej), genezy tego wymiaru, społecznych konsekwencji, przejawów historycznych i współczesnych dla wychowania i edukacji;

- eksponowanie roli emocji jako podstawy aktywności religijnej, z równoczesnym lekceważeniem i ograniczaniem czynnika intelektualnego w poznawaniu religii własnej i innych;

- brak szerszego podejmowania w działaniach wychowawczych problemów relacji wiary i nauki, szczególnie w kontekście współczesnego rozwoju nauki;

- brak wyraźniejszych działań inicjujących, z osobami wierzącymi, wątpiącymi, poszukującymi oraz kontestującymi życie religijne, w różnych grupach wiekowych rozmowy o religii, wierze chrześcijańskiej, życiu chrześcijańskim, istocie Kościoła;

- lekceważenie roli znajomości własnej religii w kontakcie z kulturami wyznawców innych religii, kształcenie błędnego przekonania, że głęboka znajomość własnej religii a także poczucie tożsamości religijnej utrudniają dialog z innymi religiami;

- zacieranie różnic między religiami, pomniejszanie różnic doktrynalnych, z kształceniem przekonania, iż porozumienie polega na wza-

${ }^{18}$ Szersze omówienie części z wymienionych błędów przedstawiam w tekście Czy religijność może być przestrzeniq sprzyjajacq edukacji międzykulturowej?, w: T. Lewowicki (red.), Religia i edukacja międzykulturowa, Cieszyn-Warszawa-Toruń 2012. 
jemnych doktrynalnych kompromisach i zależy od gotowości do takich kompromisów;

- zapoznawanie z religiami bez podkreślania sensu kultu wynikającego z ich doktryny, z odwoływaniem się głównie do najbardziej znanych i charakterystycznych zwyczajów, rekwizytów, rzadziej - poprawnie rozumianych symboli;

- małe znaczenie przywiązywane do postaw osobowych i chrześcijańskich wychowawców/nauczycieli identyfikujących się z chrześcijaństwem.

Pedagogika chrześcijańska jako nauka o różnych obszarach badawczych jest również nauką teologiczną. Ten jej aspekt musi być uwzględniany i zachowywany, jeśli ogląd wychowania chrześcijańskiego ma być pełny.

Pedagogika chrześcijańska jest subdyscypliną pedagogiki o szczególnie złożonej specyfice, a tym samym skomplikowanej tożsamości. Wymaga to wytrwałego poszukiwania takich ujęć, które pozwoliłyby na jej rozwój, a tym samym umożliwiały kompetentne i rzetelne odpowiadanie w świetle wiary chrześcijańskiej na potrzeby praktyki wychowawczej, na nowe problemy społeczne i kulturowe.

\section{Contemporary Areas of Christian Pedagogy (Summary)}

The text investigates the issue of contemporary fields of Christian pedagogy, distinguished on the basis of its identity and the specific character of its scope. The author starts off with the identity of this sub-discipline. She searches for its basis in the matter of her research. Starting points are the identity of pedagogy as the science of upbringing and the specificity of a pedagogic action, known as upbringing. The concept of various (practical, prescriptive, descriptive-experimental and theoretical) areas of pedagogy by S. Kunowski is an auxiliary concept in the analysis of the research of Christian pedagogy. According to the author the specificity of a pedagogic action is expressed by a specific combination of its two dimensions: intentionally-rational and interactive-dialogic one. Christian pedagogy may and should be present in all areas distinguished by Kunowski and also as an intentional-rational action (the fulfilment of attitudes).

The anthropological-axiological perspective of Christian pedagogy derives from a personal vision of a human being and values. It also assumes that Christian upbringing is a religious upbringing in and for Christian religion, built on the basis of personal upbringing.

The suggested areas of the research concerning Christian pedagogy include: Christian upbringing in its direct meaning (based on fulfilling directly defined objec- 
tives of Christian upbringing as a religious upbringing) and in its indirect meaning (based on Christian religion and fulfilled by an educationalist-teacher through educational actions in the intentionally accepted personal and Christian attitude).

In the final fragment of the text, the author underlines the alarming upbringing-educational situations and social-cultural phenomena which can have a negative influence on Christian upbringing and therefore are a challenge for a contemporary Christian pedagogy.

Keywords: Christian pedagogy; direct religious upbringing; indirect religious upbringing; Christian upbringing; personal upbringing.

\section{Współczesne obszary pedagogiki chrześcijańskiej (Streszczenie)}

Tekst podejmuje zagadnienie współczesnych obszarów pedagogiki chrześcijańskiej, wyodrębnianych ze względu na jej tożsamość i specyfikę zakresu. Autorka wychodzi od tożsamości tej subdyscypliny. Poszukuje jej podstaw przede wszystkim w przedmiocie jej badań. Za punkt wyjścia przyjmuje tożsamość pedagogiki jako nauki o wychowaniu oraz specyfikę działania pedagogicznego, jakim jest wychowanie. Koncepcją pomocną w analizie przedmiotu badań pedagogiki chrześcijańskiej jest koncepcja działów pedagogiki S. Kunowskiego (rozróżnienie na pedagogikę praktyczna, normatywną, opisowo-eksperymentalnej i teoretyczna). Specyfika działania pedagogicznego zawiera się, według Autorki, w specyficznym połączeniu jego wymiarów - celowo-racjonalnego i interakcyjno-dialogowego. Pedagogika chrześcijańska może i powinna być uprawiana we wszystkich wyróżnionych przez Kunowskiego zakresach, a także zarówno jako działanie celowo-racjonalne, jak interakcyjno-dialogowe (realizacje postaw).

Perspektywa antropologiczno-aksjologiczna pedagogiki chrześcijańskiej wynika z osobowego widzenia człowieka i wartości, i zakłada, że wychowanie chrześcijańskie jest wychowaniem religijnym w- i do religii chrześcijańskiej, budowanym na podstawach wychowania osobowego.

Proponowane obszary badań pedagogiki chrześcijańskiej obejmują: wychowanie chrześcijańskie w znaczeniu bezpośrednim (opartym na realizacji określonych bezpośrednio celów wychowania chrześcijańskiego jako wychowania religijnego) i pośrednim (opartym na religii chrześcijańskiej, na realizowaniu przez pedagogawychowawcę działań wychowawczych w świadomie przyjmowanej postawie osobowej i chrześcijańskiej).

W końcowym fragmencie tekstu Autorka zwraca uwagę na niepokojące sytuacje wychowawczo-edukacyjne i zjawiska społeczno-kulturowe, które mogą nega- 
tywnie oddziaływać na wychowanie chrześcijańskie, a tym samym stanowią pilne wyzwanie dla współczesnej pedagogiki chrześcijańskiej.

Słowa kluczowe: pedagogika chrześcijańska; wychowanie religijne bezpośrednie; wychowanie religijne pośrednie; wychowanie chrześcijańskie; wychowanie osobowe. 
